\title{
CHALLENGES OF THE CONSTRUCTION SECTOR IN THE GLOBAL ECONOMY AND THE KNOWLEDGE SOCIETY
}

\author{
Miguel Ángel GARCÍA \\ RTD and regional Development, CARSA, C/ Alcalá, 35. 6D, 28014 Madrid, Spain \\ E-mail:magarcia@carsa.es; Tel. +34 915310503; Fax.+34 915220626; Web: www.carsa.es; www.innovalia.com
}

\begin{abstract}
Nowadays, the Construction Sector in the EU is one of the most relevant forces of the European economy - It represents the 10\% of the total EU GDP and 7\% of total employment. Nevertheless, we can define this sector as a very unstructured activity with a wide range of interactions in the value chain. In fact, we can say it's a hyper-sector that has been demonstrating over previous decades, to be market oriented and not too much innovative. Several analyses have concluded the RTD activity in the construction Sector is quite unstructured and a lot of knowledge is produced but not recorded. In most cases, the RTD and innovation activity are focused to solve day to day problems, more than a response to an innovative policy and planned activity. Main innovations have been made in the fields of materials and machinery, and most of them could be considered as a technology transfer form other sectors. The market demand - according to economical cycles, and the financial support have been the main forces that have driven the activity of the Construction Sector. The new landscape ahead, of a global economy and a society based on technology and knowledge creation and valuation, will force this sector to be more active and structured in their RTD and innovation activity.
\end{abstract}

KEYWORDS: Construction; Networking; SME; Innovation; Competitiveness

\section{INTRODUCTION}

Conclusions included in this article are based on real experiences and outcomes of CONSTRINNONET and RICAM initiatives. CONSTRINNONET (visit www.vtt.fi/virtual/ constrinnonet/) is an EU funded project which aims to promote innovation in the construction sector at EU level. A consortium composed of several partners (VTT - Finland; CSTB France; Vilnius Gediminas Technical University - Lithuania; Paragon - Greece; Salford University - U.K.; CARSA - Spain) have faced different studies and analyses over construction sector for 2 years in their respective countries. Some pilot actions have been carried out to check and analyse which mechanisms are more effective for innovation and most convenient to innovate better and faster in the EU construction sector. Results have been compared at regional, national, EU and global scale.
As a result, the project made a State of the Art Study at global and EU scale, considering regional factors. We can mention other outcomes from this project, such the design of an EU construction network for innovation and competitiveness, the implementation of some support mechanisms for innovation activities at EU level, etc. Conclusions from this project were reported to the European Commission to be considered for future design and implementation of support programmes and initiatives for innovation in this sector at EU level.

On the other hand, RICAM (visit http:// www.itccanarias.org/ricam/) is a cluster made of SMEs pertaining the Energy, water resources and Environment sectors. It has been considered as a case study in CONSTRINNONET project due to relationships with constructions activities and for the interest of the model of organisation and relation- 
ships. This cluster is based in the Canary Islands in Spain since 2002 with the purpose to promote innovation activities between its members and foster their competitive advantage at EU and global scale. RICAM have been supported by Spanish funds for innovation. These funds come from a national initiative to support SME innovating activities. These funds are managed by regional governments, and in this case the design and implementation of the cluster have been contracted to CARSA, which is also a member of CONSTRINNONET project. This cluster promotes innovation, synergies and cooperation between its members (between 2530 organisations including SMEs, Tech. Institutes, Associations, etc.) and with other entities and networks worldwide. The Canary Islands are considered an ultra-peripheral region of the EU and its companies have to base their strategy to cooperate and compete at global level, because of limited critical mass of local markets. This cluster have been designed with a bottom-up philosophy taking into account SME needs and opportunities, implementing some shared support services, tech and competitive survey, marketing, RTD initiatives, funding, etc.. In this cluster SMEs are full right members whereas that government and researcher organisations are considered associated members. Associated members can participate in all clusters activities but without rights to vote and decide. Results and the efficiency of relationships in RICAM cluster have been considered as an example of best practices for the promotion of innovation and competitiveness of sectors. Keys of RICAM success are the concentration of resources, the promotion of synergies, co-operation and the rationalisation of expenses related to support services (most SME can't support these activities individually). Thus, results and outcomes from this cluster have been considered for analysis carried out under the CONSTRINNONET frame, to be extrapolated to an EU and global scale for the construction sector.

Based on the results and outcomes of these initiatives, it have been identified some challenges of the EU construction sector to be competitive in the frame of the global economy and the development of the so called "knowledge society". As we could discover in this article, innovation, knowledge valuation and competitiveness are terms strongly linked. With these preliminary considerations we start the analysis of most important barriers, opportunities and challenges of the EU construction sector for the future.

The level of investments in RTD activities in the construction sector is less than $0,5 \%$ of the turnover of the companies. Most innovations in this sector aren't based on basic research, and it's more a result of incremental innovations over some existing technologies. Main factors which difficult RTD activity in this sector, are linked to their idiosyncrasy:

- heterogeneous and fragmented sector,

- market driven,

- most of the projects are prototypes each building is different and are made in a different place,

- dependencies on the economic cycle,

- discontinuities in the value chain,

- intensive, non qualified and mobile work force,

- hard work conditions,

- ...

The majority (54\%) of construction enterprises are sole proprietorships ("self-employed") and micro enterprises (fewer than 10 employees) make up about $93 \%$ of all construction enterprises, and account for $50 \%$ of construction activity and $34 \%$ of turnover (against $81 \%$, $15 \%$ and $7 \%$ in manufacturing). In this scenario we'll found strong difficulties to structure innovation. The configuration and structure of this sector in a key point has to be considered for further analysis.

On the other hand, it has been identified a lack of awareness of regional institutions for the support and promotion of specific innovation initiatives for his sector. In spite of the significant impact of the sector on EU economy as a whole (e.g. 10\% of GDP and employing 
$7 \%$ of the workforce) it has been largely overlooked in regional programmes such as those promoting better innovation, technology or knowledge transfer strategies and best practice benchmarking for SMEs.

In addition SMEs aren't very proactive for the promotion of cooperative/ collaborative activities at EU and regional level and are mostly focused to solve day to day problems.

Some studies (Porter, 1990; Urteaga; 2003; Abrunhosa, 2003; The Cluster Competitiveness Group, S.A. 2002; den Hertog, et al., 1999; Roelandt, 2000; Maskell, 2001; Neven, 2000; Arvantis and Hollenstein, 1997; Bergman and Feser, 1999; Hove, Roelandt and Grosfeld, 1998) on national innovation systems have been made by organisations such as the OECD, European Commission and various national officials, showing an unstructured European construction sector which has not been very successful in adopting new technology and possibilities to its processes when compared to other "ripe" or developed sectors.

Some characteristics of real estate and construction cluster have been recognised:

- The sector is very fragmented and innovation is often a result of interactions between a numbers of different actors. Due to the fragmentation, the innovation process is neither systematic nor easily manageable.

- Demand fluctuates considerably and does not always follow the cycles of the rest of the economy.

- Business is project based; it is difficult to verify the results and impacts of innovations due to the changing conditions.

- Product or process improvement cycles are slow. The industry is reluctant to quick changes in production technologies.

- The industry's ability to manage the innovation process is not at the same level as in other industries.

- There are limitations to the risk taking in developing new solutions or products.

- The sector lacks educated personnel in companies.
- The culture in the sector is conservative and in some countries, not end-user oriented.

- Governmental control plays a significantly stronger role in innovation process than in most other sectors.

In such frame, the innovation process in the construction industry has been recognised to be neither systematic nor linear.

Some outcomes extracted from studies carried out under the scope of CONSTRINNONET project in 2003, showed us some guidelines in order to overcome all these difficulties and promote a structured innovation in the construction sector:

- Development and incorporation of advanced materials (high behaviour concrete, composite materials, lighter materials, ...);

- Incorporation (tech. Transfer) of ICT technologies from other sectors (industry, etc.);

- Progressive incorporation of pre-manufactured products and structural parts;

- Introduction of new organisational models in the construction hyper-sector integrating the value chain;

- Incorporation of innovative machinery to reduce labour and time expenses;

- Application of industrial models for the organisation of operations and logistics;

- Development of legislation affecting environment and safety conditions;

- Quality control of products;

- Improvement of professional qualifications of workers.

One of the most important key factor to improve competitiveness and to structure innovation activities in the Construction Sector, all around the EU, is the adoption of a new organisational model in which synergies and integration of the value chain will contribute to get a more efficient and innovative sector.

The experience obtained during the creation of RICAM cluster (RICAM is a recently created cluster focused to Energy, Environment and Water Resources in the Canary Islands region), will help us to understand some key aspects.

Despite this cluster has not a Construction 
focused strategy, $90 \%$ of their activity is closely linked to the construction activity, has been faced from a local initiative of SMEs supported by a regional Technology Institute and national funds. The process has started analysing some ongoing clusters at an EU and US level. Next step has been the definition of the objectives, strategy and the structure of RICAM. Following the process, a requirement analysis at regional level to identify capabilities and requirements of involved companies has been carried out. With all the gathered information a bottom-up strategy and Action Plan has been defined for the implementation of the cluster, as a result of preliminary studies (García, 2002).

A supporting activity from a consultancy enterprise and a Technologic Institute has been relevant for the definition and fostering of the structure.

The philosophy of the cluster's activity includes sharing specialised resources, the promotion of synergies, business and innovation cooperation. The structure and services of RICAM effectively support these relationships and activities. In this frame all organisations are integrated in the structure, but only SMEs have the right to vote and direct the cluster. Other kind of organisations can cooperate and participate in all activities, including the general assembly (but without vote right). Thus this is a network really market oriented, and entities like governmental and tech.\& science institutions are considered associated (in fact these organisations should focus to sell their services to SMEs, acting as providers or facilitators).

As a result, RICAM launched a set of services to support relationships and activities of the involved entities. Some of these services are:

- Business Intelligence services;

- Innovation and technology transfer support;

- Business and marketing support;

- Market analysis and prospective studies;

- Intermediary support for relationships with institutions (public and privates). Identification, biding negotiation of contracts (pub- lic and private).

As a result companies pertaining RICAM have got some benefits:

- Bigger negotiation capabilities with both providers and customers;

- Effective knowledge sharing and transference;

- Acceleration of the innovation cycle and the quality/ level of it;

- Shortening the cycle period for the valuation of knowledge from RTD activities to the market;

- Fostering RTD capabilities and results of associated companies;

- The creation of a frame of confidence and collaboration between companies (sometimes considered as a competitors).

Why to work in a Network? What are the expected Competitive advantages and benefits of Construction Innovation Networks?

Construction process itself is complex, involving a dispersed group of expert participants who have diverse RTD needs which all should result in developing high quality buildings and constructions. Firms, suppliers and services meet only when there is a project.

The evolution of the global economy and new ways for business relationships are strengthening the pressure to create richness and added value by a higher specialisation and technological competence. New conditioning factors of the economy demand a higher capability to compete at a global scale.

In this frame, the network concept represents an integrating solution, fostering the business and competitive capabilities, promoting synergies and a better exploitation of current resources (scale economy). In this way, a SME could be considered as an extension of other SME and even of the whole network. This concept of integration, have direct impact and relevance over the degree of specialisation and the rationalisation of expenses, mainly those related to business transactions between organisations. In this way, each SME can focus on their core business and get specialised services and products from the same network. 
In this way all SMEs pertaining the network will have their own objectives, but sharing common values and interests. Knowledge and innovation, are faster fostered in this frame of cooperation and confidence.

As it's has been identified by some experts (e.g. "The competitive advantage of Nations" Porter.) one of the most important key factors in a network is the creation, and faster dissemination and valuation of the knowledge. The identification and analysis of tech \& business opportunities will be a key factor in a network structure for the integration of the value chain and the promotion of synergies for the development of competitive products and services. The network dynamics will contribute to the valuation of the knowledge and the competitiveness.

Such concentration and higher specialisation of resources have to lead to a higher efficiency of related activities, integrating the value chain and contributing to a better rationalisation of associated costs as well as the competitive capabilities.

It have been demonstrated, that discontinuities in the value chain are a relevant source of inefficiencies and an obstacle to transform the knowledge into valuable goods and services for the society.

In such scenario, a construction SME will have a set of activities which could be externalised to other entity pertaining the network, and other that could be coordinated in a more competitive way.

The figure bellow shows us a set of activities which have to be deployed into the value chain. These activities have been classified into supporting and primary.

Both, primary\& support activities are of relevant importance for the SME. Primary activities are oriented to the creation and supply of a product / service toward final consumer. On the other hand, support activities will provide support to the first ones. These support activities are more horizontal and affect to the primaries, which are more vertical and linear.

From a more aggregate point of view (sector), all these activities are part of the value chain, and each one, contributes to increment the value of a done product or service. See figure bellow.

Each SME have their own business strategy which guides the way all the mentioned activities are carried out and how the value chain is organised. These SMEs get competitive advantage from the conception of new ways to deploy their activities in a more efficient way, employing new procedures, new technologies or different inputs.

These operations can be broken down into
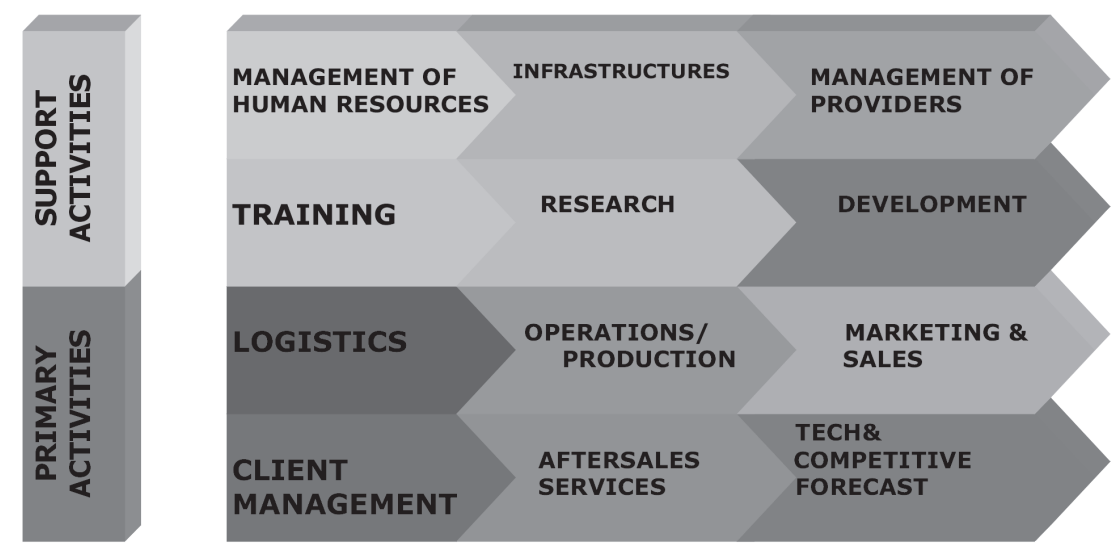

Figure 1. Diagram of activities into the value chain in a network Source: CONSTRINNONET 


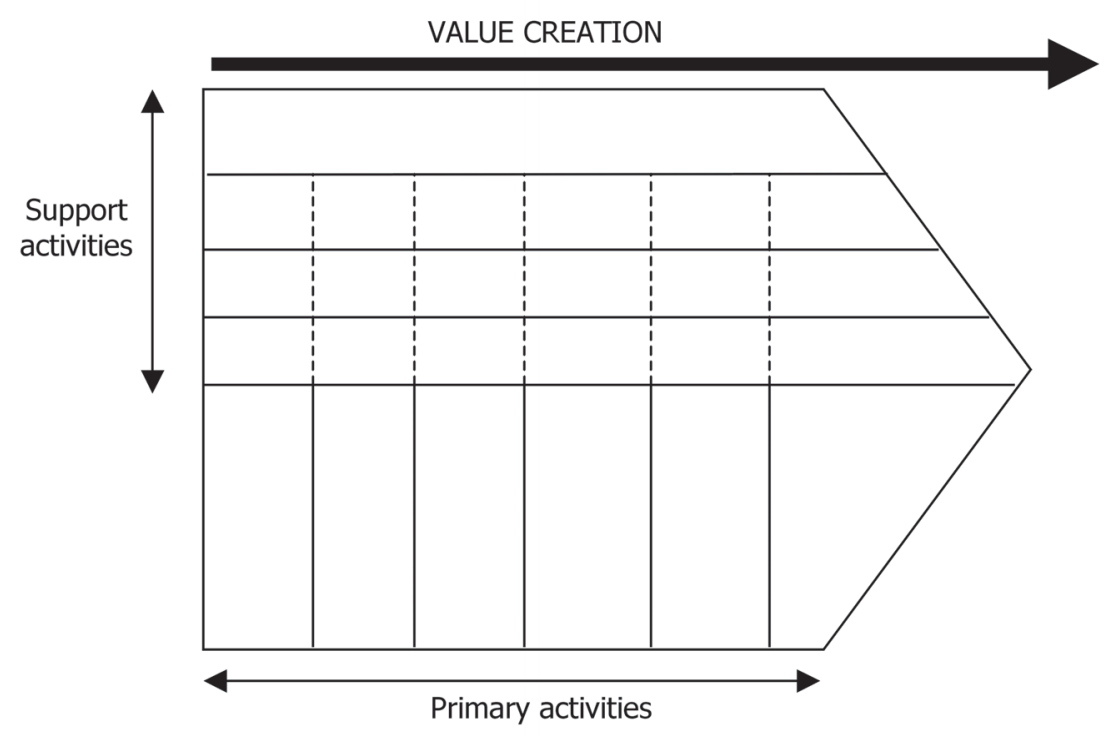

Figure 2. The value Chain process Source: Porter, 1990

a set of activities which have an associated cost. At the end of the operations these SMEs get an added value (product/ service). When this value overcome associated costs of all activities involved in the operation we can say the SME is profitable. Despite this, to get competitive advantage over their competitors, SMEs have to face the mentioned activities in a more efficient way and at the same time increase the value of resulting products\& services, and much more to deploy their activities in a unique way which leads to a relevant differentiation over their competitors.

But an enterprise is much more than the sum of these activities. The value chain in a SME is an inter-dependent system or networks of activities linked by connections and communication channels. The way these relationships are developed will affect associated costs and efficiency of other related activities. We have to consider a SME as an open entity and its activity as a set of relationships and interactions inside and with its environment.

Thus, to get competitive advantage, the SME have to assume the management of the value chain as a system rather than a group of sepa- rated parts. The most important competitive improvements come from the reconfiguration of the value chain, reordering, regrouping, reassigning and even eliminating some activities.

All these activities are in the domain of both individual and collective fields. Nevertheless, related activities are executed in a more effective way when they are deployed in the frame of a network structure due to a better availability of required resources as well as the specialisation level, taking also advantage of the scale factor, with a reduction of associated cots and expenses. At the same time the knowledge interchange between entities is promoted, creating and consolidating communication channels which will foster interactions. In this way a permanent relationships are being created between different activities both into the SME and a set of associated entities, which take advantage of new and additional opportunities for a competitive improvement.

The most relevant factor in this frame is the knowledge valuation, which gives us added value products and services. In the same way, we can asset that structuring and organisation activities into the network have to foster the 
flow from knowledge to valuable products and services. Such knowledge will originate into the network and it will be partially a result of information interchange between tech. demand \&offer.

See figure bellow. Knowledge flow and its materialisation into products and services.

Nowadays, the technology can be sold and bought everywhere all around the world. Thus, the competitive advantage can be acquired trough the creation, application and valuation of knowledge to increase the added value of related products and services. It has been demonstrated, that the decentralization and outsourcing process doesn't affect those SMEs with more knowledge-based activity.

The problems in this sector are related to the fragmentation and dispersion of existing knowledge and capabilities.

In this scenario, the network and association strategies appears to be the most adequate way to structure and foster innovation in the Construction Sector, integrating innovation activities in the value chain. The collaborative model for RTD activities integrating providers\& costumers is a very competitive option. In addition, a support activity and interactions with the science/technology/ business system has to be articulated and facilitated with a set of initiatives. In this case entities involved in the technology and innovation brokerage at a regional\& national level will deploy a catalytic role.

\section{NEW CHALLENGES AND FRAMEWORK}

The competitiveness and innovating possibilities of construction SMEs depend not only of internal factors. Some other key factors of their environment will also deploy a relevant role in its behaviour and innovation activity.

Some innovations and progresses have to be fostered from the construction itself in order to improve its efficiency and competitiveness. On the other hand we have to remind, that the Construction Sector is a market driven activity, thus the role of regional, national and EU organisations can be relevant in their deployment. The development of coherent EU regulations for environment and quality issues, related to the construction sector has to be promoted in the future. For example, the energy consumption optimisation in this sector is to be faced, mostly taking into account the Kyoto protocol to be applied. The energy con-

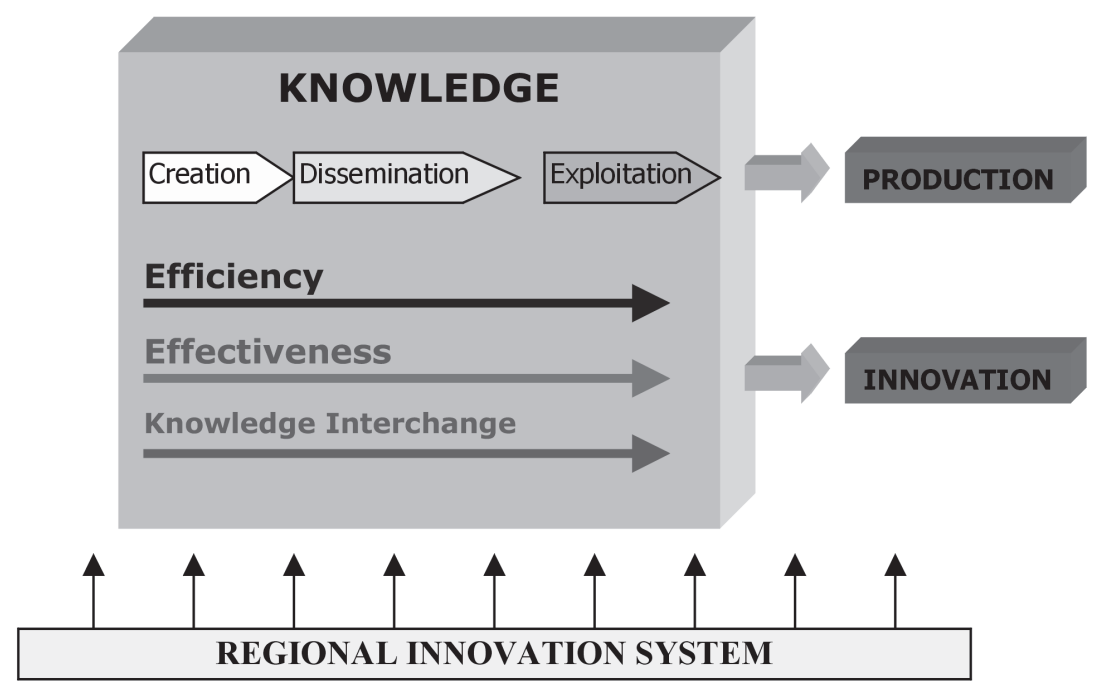

Figure 3. Knowledge flow and their materialisation into valuable products and services Source: CONSTRINNONET 
sumption analysis should be applied not only in the construction phase, but in the whole life of the building. For this purpose we'd need a category system to classify buildings taking into account its isolation and energy needs (like in electronics and house ware devices). The establishment of EU standards and regulations could be very useful.

In a nowadays scenario of global economy and continuous change, a set of pilot actions carried out by CONSTRINNONET project in 2003, have identified some challenges for the future development of the constructions sector in the EU:

- Implementation of quality and EFQM models in the sector (nowadays is weakly applied quality procedures and concepts in this sector, both for materials and activities).

- Improvement of qualification and training of labour force (the massive incorporation of new labour mass from third countries requires with very low professional profile requires training activities to ensure a minimum qualification).
- Assessment and prediction of differences between demand and offer in the construction sector (the growing difference between demand and offer, causes continuous growing rates of building prices and generates some stresses in regional economies).

- Development and implantation of new organisational models for a better integration of the value chain as well as for the coordination of innovation and business activities.

As a result of some pilot actions carried out to foster innovation in the Construction Sector in the EU, under the activity of CONSTRINNONET project, analysis on such pilot activities have revealed some key aspects and recommendations to be taken into account:

- The implementation of supporting services for innovation activities in the Construction Sector, have to consider regional idiosyncrasy of involved entities. In addition, a bottom up focus has to be implemented. The Construction Sector has to share some common objec-

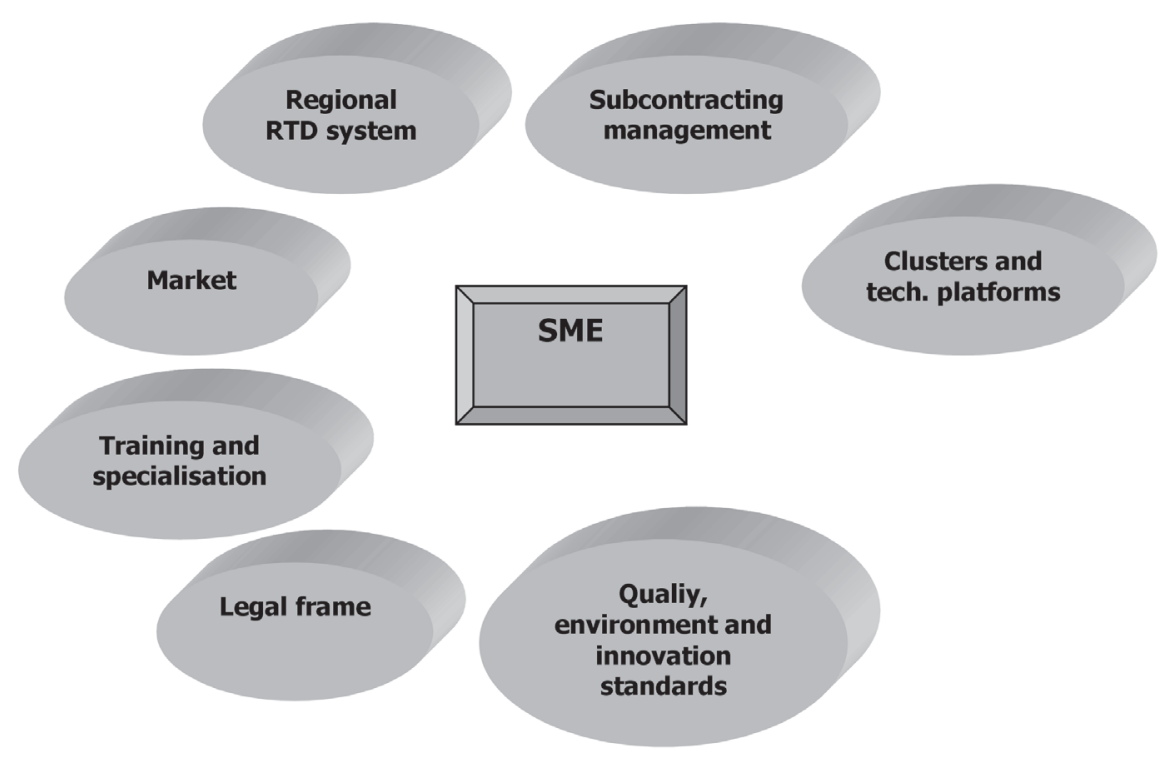

Figure 4. External factors of construction SMEs 
tives and strategies, but each SME have to identify a clear and concise benefit it can get from their involvement in related activities.

- Brokerage activities with SMEs have to be focused to business opportunities they could get benefit from tech collaboration. Innovation\& tech. development have to be considered as a tool to get competitive advantage in a dynamic market.

- Awareness and regional support by regional institutions are essential as well as the involvement of regional entities. These regional resources and capabilities have to be identified and taking into account for the establishment of a relationship frame of innovation opportunities at an EU level. Thus regional support should be faced by these entities, and the EU frame (clustering/ network) should be supported by a set of reliable services to support knowledge interchange (information/ best practices, etc.), technology exchange (offer/ demand matching) and a platform for the effective development of cooperation projects between EU entities.

- Brokerage activities for tech and businesses issues have to be driven by enterprises with support of intermediate entities. On the other hand, networking activities have to be lead by those intermediate entities promoting the active involvement of enterprises (with special focus on SMEs).

The implementation of support services for the promotion of innovation activities in the Construction Sector in the EU, have to consider the different intensity of support the SMEs could demand from a merely information supply to a business/ tech. cooperation platform.

This is a very fragmented sector and the dynamics of the value chain have to be carefully considered in each region. Thus, to get relevant results from innovation activities, we should consider these relationships and the way to found synergies in this ecosystem promoting improvements and competitive advantage both into the internal processes/ activities and interactions between companies. This activity will require the promotion of a clustering/ networking culture both for business and innovation related issues. Conclusions from some CONSTRINNONET studies reinforce this point of view (García, 2004).

All these recommendations and guidelines should be directed to:

- Regional development institutions. The clustering/ networking culture will require the regional support of related institutions.

- European Commission: The implementation of an EU innovation Network for the Construction Sector will require a financial/ institutional support from the EC. Regional institutions will provide support at regional level and EC should contribute to support services for inter regional interactions.

- Construction associations. Responsibility for awareness and training issues. They should actuate as an information channel and interface between the local and EU levels. A significant awareness activity over these associations is required for their involvement in EU related initiatives.

- Construction construction-related SMEs. Increase the knowledge level and promote the culture for innovation and cooperation.

- Intermediate entities (Tech institutes, Universities, etc.). Promotion of tech. and knowledge and their valuation for the introduction in the market.

Some of the supporting activities we have identified of relevant impact for the involvement of construction SMEs in innovation related activities at EU level requires a different strategy for their implementation. For example, those related to dissemination activities will imply a significant extensive effort but less in- 


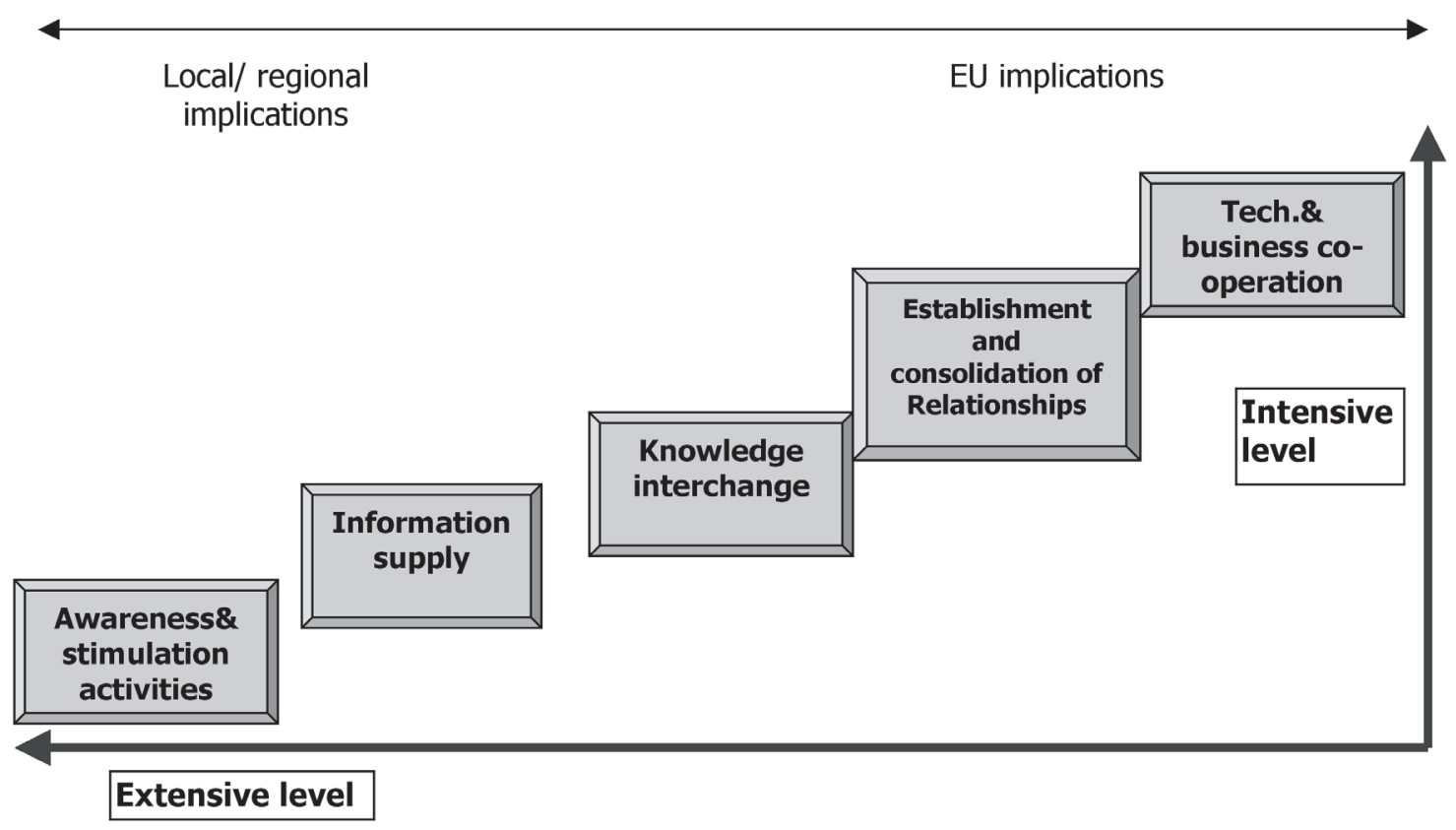

Figure 5. Regional and EU implications in the promotion of innovation in the Construction sector Source: CONSTRINNONET

tensive activity. On the other hand, some specific activities such as the promotion and support of cooperation projects at EU level will require more intensive activity but less extensive dimension. The figure bellow illustrates, the strategy (application of the effort) to be considered as a function of the service to be implemented (see figure above).

\section{THE ROLE OF NETWORKS}

Main strategy of recently developed organisational models is focused to develop and foster SME's capabilities in order to allow the projection of their productive processes, their individual and network strategies, at the same rate as their markets, by a concerted action between the SMEs and their environment.

Thus, the co-ordination of activities (both individual and collective) and in the value chain are promoted and well supported.
In order to get the network operative, we have to take into account that the main priority is to develop capabilities (individual and collective) as well as a culture for the global competitiveness and co-operation in the value chain.

The knowledge\& technology interchange give us a competitive advantage promoting the innovating activity of their members and fostering the valorisation of such knowledge into products\& services.

From these interactions and interchanges of knowledge all members get competitive advantage in relation with potential competitors.

The stating point for the creation of a network comes from the implementation of a common strategy for the application of technology\& business policies to get competitive advantage of already existing resources (the implementation of new resources is quite difficult due to associated costs and limited results in a short term). 


\section{CONCLUSIONS}

Some structural characteristics of the construction industry reveal specific features highly defined which differentiate from other sectors and force to face their own problems.

In fact, the demand is concentrated over a set of products which typology is characterized by the following conditionings:

- There is no possible the serial production;

- The geographic locations force to move all the production system to the consumer location, being no possible the storage and distribution of the final products;

- A continuous evolution in our society toward a complex and specialized requirements;

- The Energy and Environment restrictions have an important influence on related activities.

In addition, as a consequence of demanded product's characteristics, appear some technological and organizational conditions in the offer side:

- geographical spreading of resources and their activity;

- a intensive utilization of the work force and a low level of capital investment;

- a low productivity of labor force (less that $50 \%$ of manufacturer industry);

- low interest of this sector in the labor market (sector qualified with the three Ds: Dirty, Dangerous, Difficult);

- predominance of small enterprises (more than $90 \%$ of the existing firms are under 10 employees);

- Limited concentration degree (the most important firms collect together a low percentage of the total production).

These environmental factors, gives us some Market characteristics:

- a clear disclosure among design phase and production, that move the builder away form the end user interests;

- high diversity of participating actors;
- the high business risk has as a consequence a deficient definition of the initial objective of the contract and limitations for their progressive improvement with successive projects\& works. In addition the impossibility to predict all the future contingencies of their activity limits the possibility to improve contract conditions;

- a clear dominance of biddings;

- a great dimension of their activity, being the second sector from the added value point of view (the first one is metal production, machinery and equipment) (OECD).

A typical discussion in this sector, focus on the fact that companies are continuously developing prototypes (all their works are prototypes) and have to face the possibility to apply innovation models from other sectors. Building companies innovate in the building processes, but these innovations are carried out directly at work places to solve specific problems of a done building. This implies to have a fast response to daily problems, and it's difficult to structure into a continuous RTD activity. The result is that building companies are continuously innovating but, without support of a structured RTD activity.

It has been evidenced in EU countries like Germany, United Kingdom, France, United States, Spain that companies pertaining the Construction Sector, have a very limited role on the RTD activities of the whole country as it has been evidenced by some studies (Eurostat, 2004; Cotec Foundation, 2000; European Commission, 1997; ENCORD, 1994). An exception could be found in Japan, where companies show a cultural heritage and tradition in RTD activities with a significant relation RTD effort/ turnover.

Main factors which difficult RTD activity in this sector, are linked to their idiosyncrasy:

- heterogeneous and fragmented sector,

- most of the projects are prototypes,

- dependencies on the economic cycle,

- discontinuities in the value chain, 
- intensive, non qualified and mobile work force,

- hard work conditions,

- ...

These companies found difficulties facing RTD activities due to the fact that related results are difficult or impossible to patent, and can be easily copied by other entities in a very short period of time.

As a corollary we can say the RTD activity in the Construction Sector is quite unstructured and a lot of knowledge is produced but not recorded.

The design of a future EU Construction Network has necessarily to consider the regional approach:

- Adaptation to local frame (regulations, habits, ...);

- Deep knowledge of local conditions (resources, demand, local problems\& restrictions, culture, climate, ...);

- More dynamic relationships and interactions at a local scale;

- Closely approach of innovation activities to local needs

and The EU dimension considering a set of relevant advantages:

- Knowledge\& tech. transfer with other entities in other regions which are facing similar problems;

- Competitive advantage of the Scale factor;

- Gain Critical mass;

- Wide set of specialised areas;

- Greater dimension of innovation activities and their impact:

o Intensive (more specialised activities, more available resources, deeper RTD activity, ...);

o Extensive (wider and quicker dissemination of activities and results throughout sectors and regions).

- Wide scope of opportunities (both for innovation and business activities).

In addition a standards and homogeneous legal frame for the Construction Sector should be forced in order to establish the contour con- ditions of market driven activity. These topics will establish some basic rules to guarantee some basic principles (quality, environment, etc. ...) in benefit of citizens and regional economies. On the other hand, trans regional cooperation between construction SMEs should be fostered, in order to promote the innovation system and their competitiveness. The creation of an EU construction platform and the establishment of a specific area in the VII EU Framework Program will notably help the EU development of the sector.

As a conclusion we recommend the establishment of a wider dimension in regional, technology, legal and social points of view and considerations, being the only way to face the nowadays challenges of the Construction Sector at EU level.

\section{Acknowledgement}

This work has been partly funded by the European Commission through IPS Project CONSTRINNONET (Promoting Innovation in Construction Industry SMEs) (No. IPS-200000002). The author wish to acknowledge the European Commission for their support.

\section{REFERENCES}

Abrunhosa, A. (2003) The National Innovation Systems Approach and the Innovation Matrix, DRUID summer conference, Copenhaguen.

Arvantis, S. and Hollenstein, H. (1997) Innovative Activity and Firms' characteristics: An Exploration of Clustering at Firm Level in Swiss Manufacturing, OECD Workshop on cluster Analysis and Cluster-based Policy, Amsterdam.

Bergman, E. M. and Feser, E. J. (1999) Industry Clusters: A Methodology and Framework for Regional Development Policy in the Unites States, Paris: OECD.

The Cluster Competitiveness Group, S.A. (2002) Competitiveness. Cluster-based policies.

Cotec Foundation. (2000) Innovation in the Construction Sector, Spain. 
ENCORD. (1994) RTD in the Construction Industry. A Challenge for Europe.

European Commission. (1997) Panorama de l'Industrie Communitaire, Brussels.

Eurostat. (2004) Euro Indicators, News release, 142/2004, Brussels.

García, M. Á. (2002) Design, structure and management of a cluster for Renewable Energy, Environment and Water Resources in the Canary Islands region, RICAM conference, Spain: Technical Institute of Canary Islands.

García, M. Á. (2004) A visionary approach for the future of Construction networks along the $E U$, Constrinnonet project.

den Hertog, P. et al. (1999) Approaches to cluster analysis and its rationales as a basis of policy, University of Brighton.

Hove, N., Roelandt, Th. J. A. and Grosfeld, T. (1998) Clusters Specialisation Patterns and Innovation Styles, Dutch Ministry of Economic Affairs, The Hague.
Maskell, P. (2001) Knowledge Creation and Diffusion in Geographic Clusters: Regional Development Implications, Business Studies, Copenhagen: Center for Economic and Business Research.

Neven, D. (2000) A Diamond for the Poor? Assessing Porter's Diamond Model for the Analysis of Agro-Food Clusters in the Developing Countries, Michigan: Dept. of Agricultural Economics, Michigan State University.

Porter, M. E. (1990) The competitive Advantage of Nations, The Free Press.

Roelandt, Th. J. A. (2000) New Policies for the New Economy. Cluster-based Innovation Policy: International Experiences, $4^{\text {th }}$ Annual EUNIP Conference, Tilburg, The Nederlands.

Urteaga, J. M. (2003) Keys for guiding innovation in management in small and medium firms. Knowledge and innovation as keys to company competitiveness, Spain: Knowledge cluster of the Vasque Country, p. 30-39.

\section{SANTRAUKA}

\section{IŠŠŪKIAI STATYBOS SEKTORIUI GLOBALINĖJE EKONOMIKOJE IR ŽINIŲ VISUOMENĖJE}

\section{Miguel Ángel GARCÍA}

Šiuo metu ES statybos sektorius yra viena svarbiausiu Europos ekonomikos jeggų: jis sudaro $10 \%$ viso ES BVP bei $7 \%$ viso užimtumo. Tačiau šis sektorius pasižymi labai nesisteminga veikla, turinčia ịvairiausių sąveikų verčiu grandinëje. Faktiškai galima sakyti, kad tai yra išaugęs sektorius, kuris pastaraisiais dešimtmečiais demonstravo, kad yra orientuotas į rinką ir nekuria daug inovacijų. Tyrimai rodo, kad mokslinių tyrimų ir technologinès plètros veikla statybos sektoriuje yra gana nesisteminga, ir didelè žinių dalis sukuriama, tačiau neužfiksuojama. Daugeliu atveju moksliniai tyrimai ir technologine plètra bei inovacijų kūrimas skirti kasdienėms problemoms spręsti. Jie nėra reakcija ị inovacijų politiką ir neprimena planuotos veiklos. Pagrindinės inovacijos buvo sukurtos medžiagų ir îrenginių sferoje, o daugelis jų gali būti taikomos kitų sektorių technologijoms tobulinti. Rinkos paklausa, keliama ekonomikos ciklų, bei finansinè parama buvo pagrindinès varomosios statybos sektoriaus jegos. Naujas požiūris, žengiantis globalinès ekonomikos, taip pat technologijų bei žinių kūrimu ir vertinimu pagrịstos visuomenès priekyje, privers ši sektorių aktyviau ir sistemingiau plètoti mokslinių tyrimų ir technologinès plètros bei inovacinę veiklą. 